\title{
Fungal Plant Disease Management by Natural Essential Oils
}

\section{BANAFSHEH SAFAEI-FARAHANI ${ }^{1}$ and \\ REZA MOSTOWFIZADE-GHALAMFARSA ${ }^{2}$}

1-Plant Protection Research Department, Fars Agricultural and Natural Resources

Research and Education Center, AREEO, Shiraz, Iran (凹b.safae@areeo.ac.ir)

2-Department of Plant Protection, Shiraz University, Shiraz, Iran

Received: 30.08 .2018

Accepted: 16.02.2019

Safaei-Farahani B. and Mostowfizade-Ghalamfarsa R. 2019. Fungal plant disease management by natural essential oils. Plant Pathology Science 8(1):24-37.

DOI: 10.2982/PPS.8.1.24.

Abstract: Essential oils are hydrophobic, volatile and aromatic compounds that have been used as fragrances and flavors for a long time. Recent studies have shown that some plant essential oils have fungicidal effects against some important plant pathogens. For instance, the essential oil of thyme inhibits the mycelial growth of Penicillium italicum and the essential oil of lavender shows the fungistatic effect on Botrytis cinerea, Rhizopus stolonifer and Aspergillus niger. The essential oil of thyme has also been used to control the black rot of orange caused by Alternaria citri and grey mold of strawberry fruits caused by Botrytis cinerea. Antifungal activities of essential oils are mainly related to their effects on fungal cell wall, cell membrane, mitochondria and nitric oxide level. As a result of increased concern about harmful chemical pesticides, essential oils can have a good place in the market as natural fungicides. In this paper, application of essential oils as natural fungicides, their mode of actions and some safety aspects of their application have been discussed.

Key words: Thyme, Lavender, Aspergillus

$$
\begin{aligned}
& \text { مديريت بيماريهاى قارجى كياهان با اسانسهاى طبيعى } \\
& \text { بنفشه صفايى فراهانى ' هو رضا مستوفىزاده قلمفرسا ' }
\end{aligned}
$$

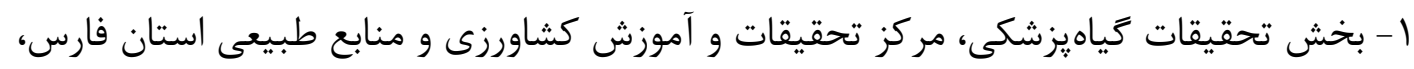

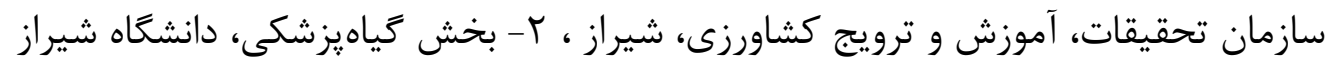

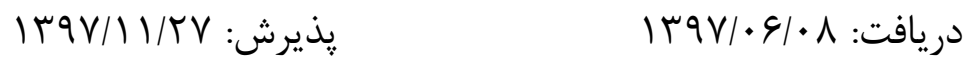

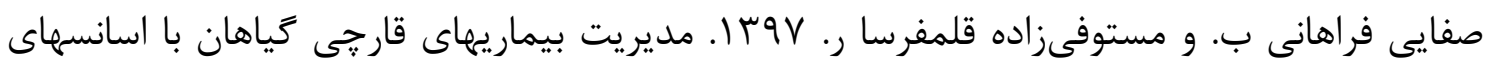

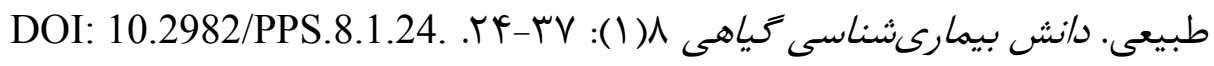

$$
\begin{aligned}
& \text { جكيده: اسانسها تركيبات آب گريز، فرار و معطرى هستند كه از ديرباز به شكل مواد خوشبوكننده و }
\end{aligned}
$$

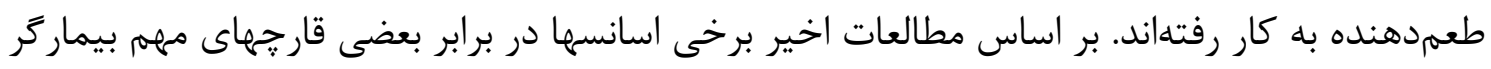

$$
\begin{aligned}
& \text { b.safae@areeo.ac.ir. : }
\end{aligned}
$$


كياهى، خاصيت قارٌ جكشى نيز دارند. به عنوان مثال اسانس آويشن باغى رشد Penicillium italicum و اسانس اسطوخدوس رشد Rhizopus stolonifer Botrytis cinerea، Aspergillus niger را به طور كامل در محيطكشت متوقف مى كنند. از اسانس آويشن باغى براى مهار يوسيدكى سياه يرتقال ناشى از Alternaria citri و كيك خاكسترى توتفرنكى ناشى از Botrytis cinerea نيز استفاده شده است. فعاليت ضد قارجى اسانسها اغلب ناشى از تأثير آنها بر ديواره سلولى، غشاى سيتويلاسمى، عملكرد ميتوكندريايى و ميزان اكسيد نيتريك در سلولهاى قارجى است. با توجه به افزايش نكرانيها درباره مضرات قارجكشهاى شيميايى، اسانسها به عنوان قارجكشهاى طبيعى مىتوانند بازار خوبى به دست آورند. در اين مقاله، استفاده از اسانسهاى گياهان به شكل قارجكشهاى طبيعى، نحوه اثر و جنبههاى مربوط به سلامت آنها مورد بحث قرار گرفته است. وازههاى كليدى: آويشن، اسطوخدوس، Aspergillus

استفاده بىرويه از آفت كشها با ايجاد مشكلات زيستمحيطى متعدد، سبب بروز نخرانيهاى عمومى

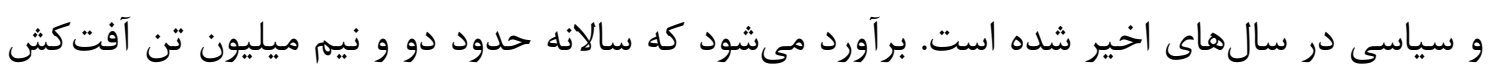
در دنيا به كار مىرود (Arshad et al. 2014). آفت كشها به دليل ماهيت تجزيهنايذير، سميت بالا و آلودكى منابع آبى و خاكى سلامت عمومى را تحت تأثير قرار مىدهند، بنابراين يافتن آفت كشهاى تجزيهيذير و كمخطر كه علىرغم حفظ عملكرد محصولات كشاورزى، حافظ محيطزيست باشند مورد توجه بسيارى از يزوهش جايكزين مناسبى براى آفتششهاى شيميايى هستند و قادر هستند اثرات منفى آنها را بر سلامت انسان و محيط زيست كاهش دهند (Arshad et al. 2014,Isman and Machial 2006 ). اسانسها تركيبات آبگريز، فرار و معطرى هستند كه به عنوان متابوليت ثانويه در ريشه، ساقه، برگ، يوست، گل و ميوه گياهان مختلف وجود داشته و در جذب يا دفع حشرات و حفاظت گياهان در برابر گرما يا سرما نقش دارند. به دليل ماهيت معطر و بسيار فرار اسانسها، از آنها در توليد عطر و جاشنى غذا و ضدعفونى كنندهاى طبيعى استفاده مىشود. مدارك موجود نشان مىدهد كه اسانسها بيش از . . ب سال قبل در مصر، هندوستان و ايران توليد و استفاده مىشدند، اما استفاده از آنها در ارويا احتمالاً از قرن شانزدهم ميلادى آغاز شده است (Burt 2004, Guenther 1944 ). روشهاى مختلفى براى استخراج اسانسها وجود دارد كه در بين آنها مىتوان به تقطير، فشردن، استفاده از حلال و روغنهاى جاذب اشاره كرد. تقطير معمولترين روش استخراج اسانس از زياهان است. اسانسها به 
دليل نايايدارى و تجزيهٍذيرى بايد در تاريكى و شرايط نفوذنايذير در برابر هوا انبار شوند تا تغييرات ساختارى در آنها اتفاق نيفتند (Burt 2004,Guenther 1944). با وجود شناسايى فعاليت ضدميكروبى اسانسها از زمانهاى قديم، امكان استفاده از آنها براى مهار بيماريهاى گياهى تنها در سالهاى اخير مورد توجه قرار كرفته است (Lazar et al. 2010)

$$
\text { ا - اثر ضدميكروبى اسانسها }
$$

تاكنون خصوصيت قارجكشى در اسانس گياهان مختلف مشاهده و گزارش شده است كه از ميان

آنها مى توان به آويشن شيرازى (Zataria multiflora Boiss)، ميخك ( Syzygium aromaticum (L.) Mentha (Merr. and L.M.Perry (Zingiber officinale Rosc.) و رزمارى (Rosmarinus officinalis L.) ونجبيل) اشاره (Rita L. Sرد (Tripathi et al. 2008, Espitia et al. 2012, Sturchio et al. 2014, Kishore et al. 2007 (Mohammadi et al. 2015, Ramezanian et al. 2016
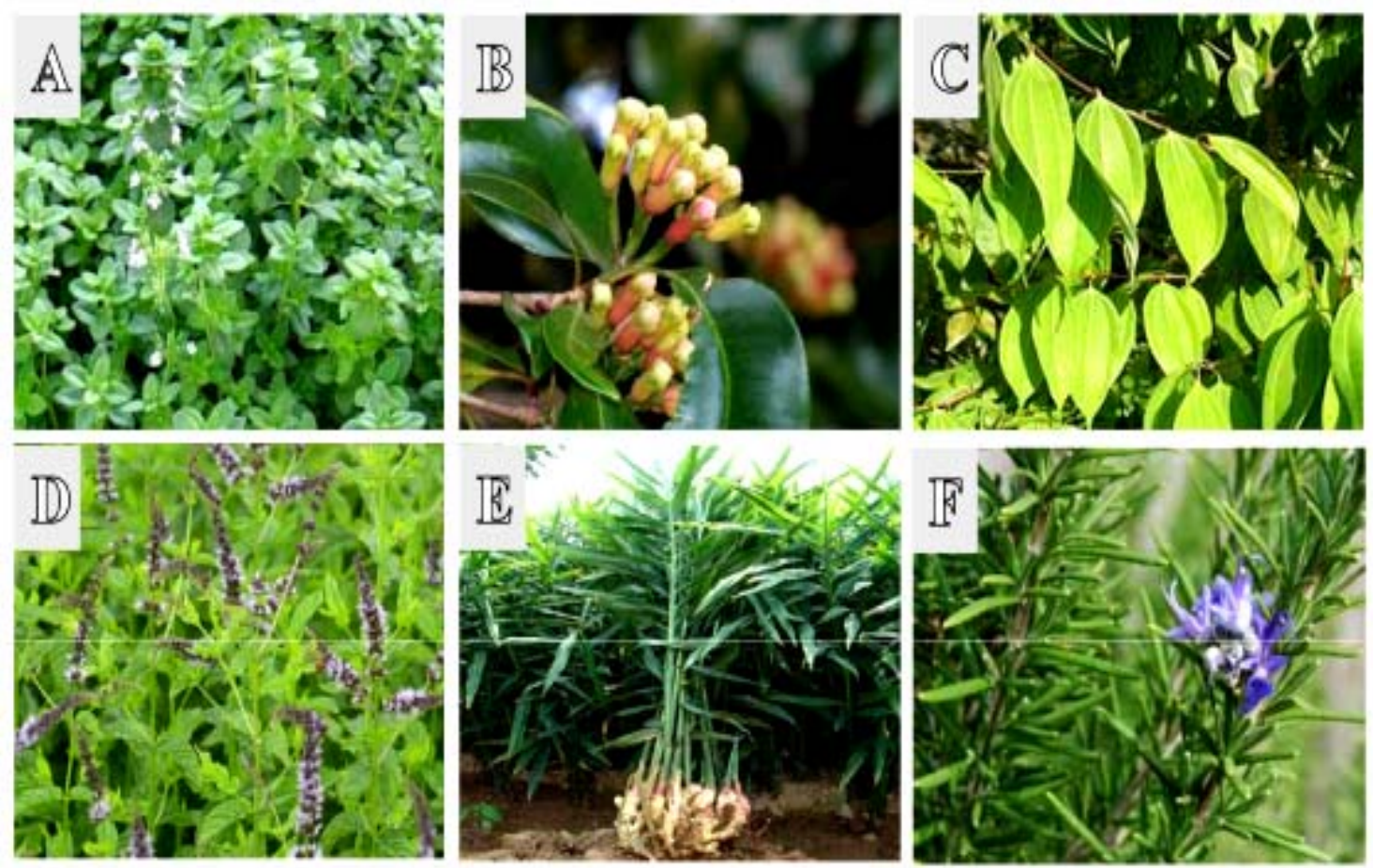

شكل ا-A: آويشن شيرازى (Zataria multiflora)، Byzygium aromaticum)، ميخك (S):

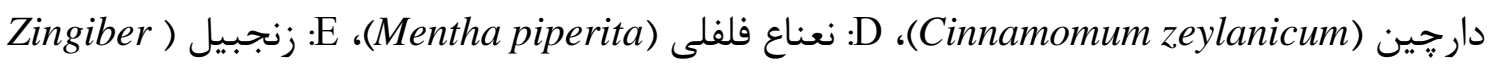

(Rosmarinus officinalis) (officinale

Figure 1. A: Shirazi thyme (Zataria multiflora), B: Clove (Syzygium aromaticum), C: Cinnamon (Cinnamomum zeylanicum), D: Peppermint (Mentha piperita), E: Ginger (Zingiber officinale), F: Rosemary (Rosmarinus officinalis). 
اسانسها تركيب بِيجيدهاى دارند كه شامل الكلها، آلدهيدها، كتونها، فنولها، استرها، اترها، ترينها و ترينوييدها در نسبتهاى مختلف است. ترينها و ترينوييدها مهمترين تركيباتى هستند كه سبب

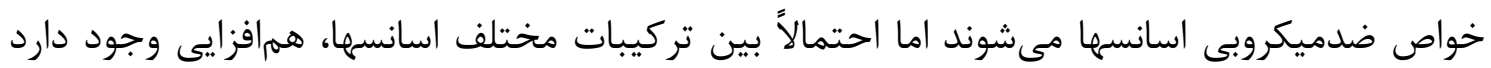

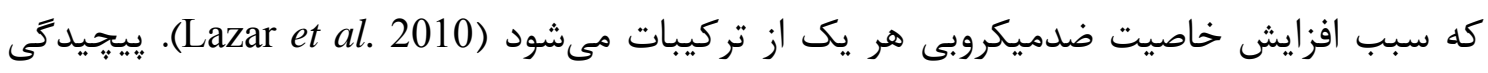
تركيبات موجود در اسانسها، تأثير مثبتى بر كاربرد اسانسها در مديريت بيماريهاى كياهى دارد، زيرا

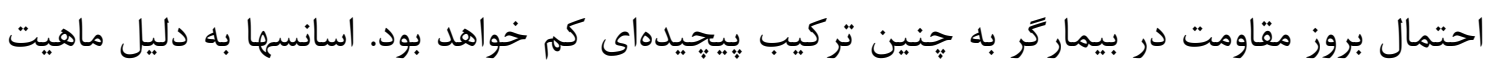

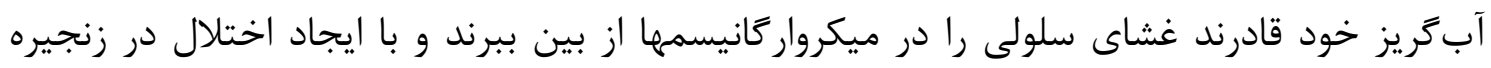

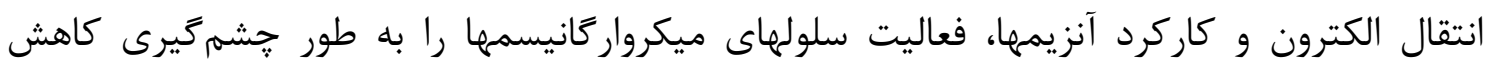

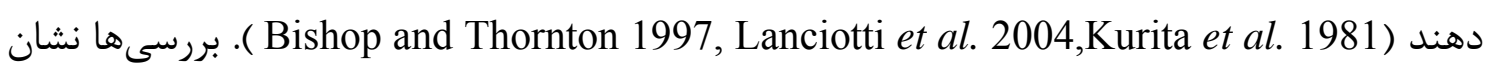
داده كه اسانسها قادر به ايجاد تغييرات در ساختارهاى قارجى هستند. به عنوان مثال اسانس مركبات Aspergillus niger Tiegh. سبب تغيير ديواره ريسه، كاهش قطر ريسه و از بين رفتن كنيديومبرهاى مىشود (de Billerbeck et al. 2001, Sharma and Tripathi 2006,Zambonelli et al. 1996. بروز جنين اختلالهايى به دليل تأثير اسانسها بر ديواره، غشا و ساختمان سلولى و فرآيندهاى درون

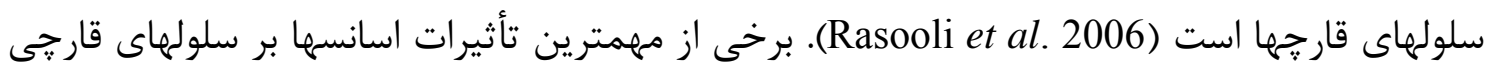
عبارتند از: تأثير بر ديواره سلولى: ديواره سلولى، نقش مهمى در رشد و زيستايى قارجها دارد. حكلوكان و كيتين مهمترين تركيبات ديواره سلولى در اغلب قارجها هستند، بنابراين جلوكيرى از توليد اين تركيبات در

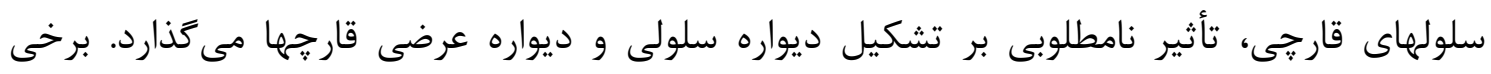

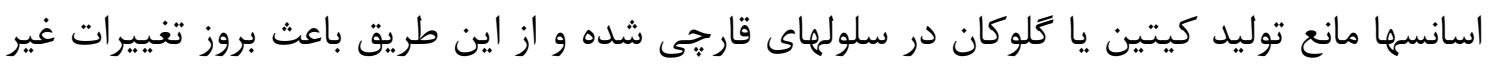

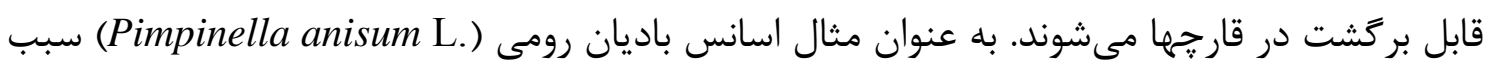
بروز تورم ريسه و تغييرات ريخت شناختى در .Mucor mucedo (Tode) Pers مىشود. اين تغييرات

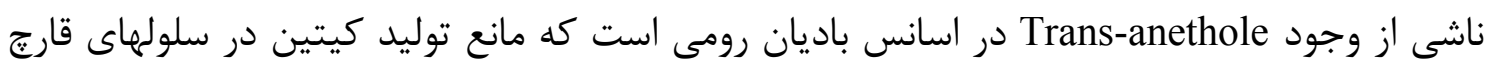
مىشود (Yutani et al. 2011). تأثير بر غشاى سيتويلاسمى: غشاى سيتويلاسمى ساختارى انعطافيذير از جنس فسفوليييد و يروتيين است كه در اطراف سلول قرار كرفته و در تنظيم ورود و خروج مواد از سلول نقش مهمى

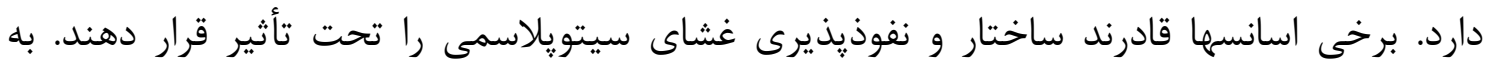

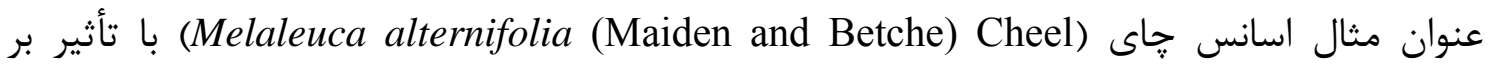
غشاى سيتويلاسمى و ديواره سلولى Candida albicans (C.P. Robin) Berkhout باعث مىشود 
شكل ريسهها تغيير كرده و به لولههاى خالى از سيتويلاسم تبديل شوند (Hammer et al. 2004). اسانس سياهدانه (Nigella sativa L) نيز تأثير مشابهى بر غشاى سيتويلاسمى و ديواره سلولى قار جها دارد (Iscan et al. 2016) تأثير بر ميتوكندرى: ميتوكندرى اندامكى است كه در ذخيره انرزى در سلول به صورت ATP (آدنوزين ترى فسفات) نقش دارد. برخى اسانسها موجب آسيب به ميتوكندرى شده يا بر كارايى آن

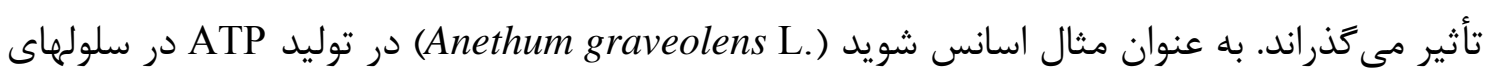
Origanum اختلال ايجاد مى كند (Chen et al. 2013). اسانس مرزنجوش (Candida albicans (Compactum و كافور (Cinnamomum camphora (L.) Nees and Eberm) نيز سبب آسيب به ميتو كندريهاى Saccharomyces cerevisiae مىشوند (Bakkali et al. 2006). تأثير بر ميزان اكسيدنيتريك در سلولهاى قارجى: اكسيدنيتريك(NO) در حفاظت از ميسليوم قارجها در برابر تنشها و آسيبهاى محيطى مثل آسيبهاى ناشى از تنشهاى گرمايى نقش دارد (Kong et al. 2012). برخى اسانسها قادرند با كاهش ميزان اكسيد نيتريك در سلولهاى قارجى باعث افزايش حساسيت قارجها به تنشها شوند. به عنوان مثال Thymol كه يكى از مهمترين اجزاى اسانس آويشن است با تأثير بر ميزان اكسيدنيتريك سبب بروز خاصيت ضدقارجى در برابر Shen et al. 2016) شده است flavus Link

ז- خواص ضدقارجى اسانسها برقارجهاى بيماركر زياهى در آزمايشهاى در شيشه و در زيوه براى بررسى اثر اسانسها بر قارجهاى بيمار گر زياهان در آزمايشهاى در شيشه معمولاً از روشهاى بهاى رقيقسازى روى محيطكشت حاوى آكار (Agar dilution) و انتشار ديسكى (Disc diffusion) استفاده مىشود. در روش رقيقسازى روى محيطكشت حاوى آكار، ابتدا اسانس در حلالهاى آلى مانند اتانول حل شده، سيس پيش از جامد شدن، محيط كشتهاى حاوى آَار، در رقتهاى موردنظر به آنها افزوده مىشود. يس از جامد شدن محيط كشت، قارج مورد آزمايش روى آن كشت شده تأثير اسانس روى رشد، اسيورزايى، ريختشناسى و ساير ويزگى هاى قارج مورد بررسى قرار مى گيرد. در روش انتشار ديسكى، يك ديسك كاغذى در اسانس خيسانده شده، روى محيط كشتى كه با

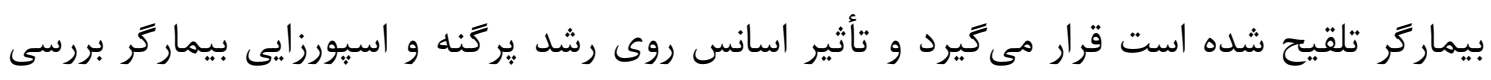

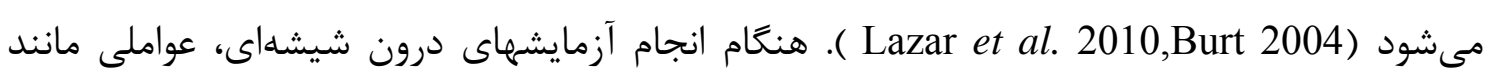
فرمولبندى (Formulation) و غلظت اسانس، يرآزارى و ميزان مايه قارج بيمارگر ، دما و pH محيط بر نتايج آزمايش تأثير كذاشته و حتى سبب يافتن نتايج متناقض مىشود بنابراين لازم است شرايط 
استانداردى براى بررسى خواص ضدقارجى اسانسها در برابر بيماركرهاى كياهى در آزمايشهاى درون شيشهاى در نظر كرفته شود (Burt 2004, Souza et al. 2005,Hadacek and Greger 2000).

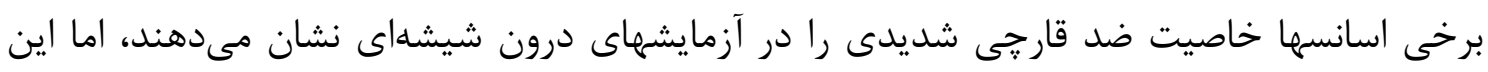

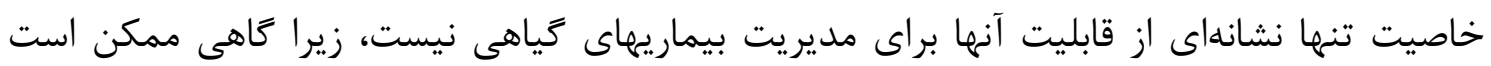

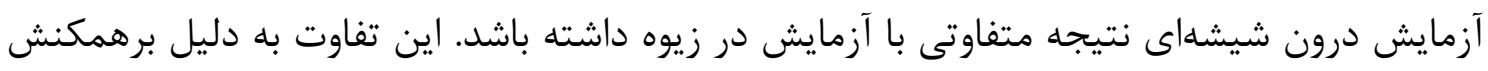

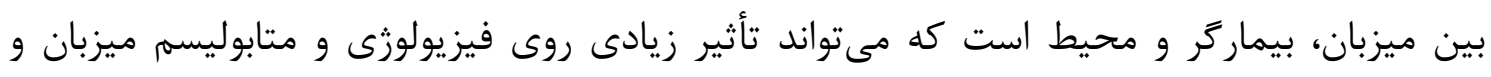

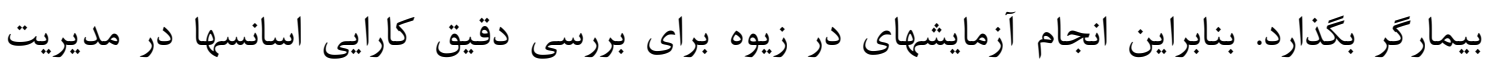

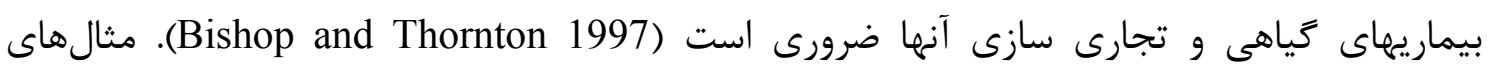

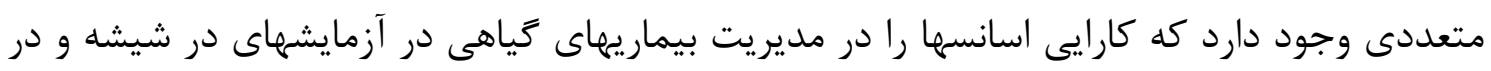

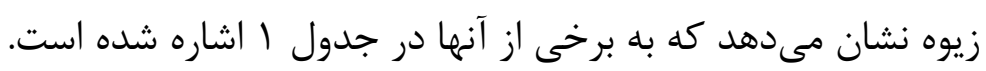

\section{ץ- خالشهاى استفاده از اسانسها در مديريت بيماريهاى كياهى}

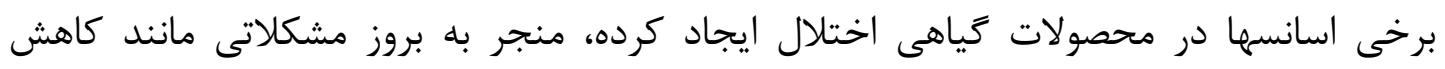
تنفس، افزايش نفوذيذيرى سلولها و جلوكيرى از ساخت كلروفيل مىشوند ( Mishra and Dubey

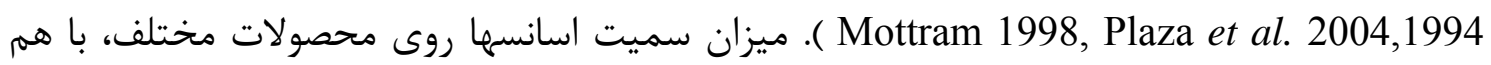

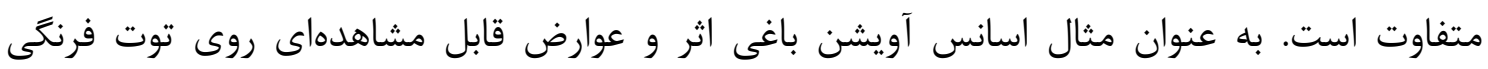

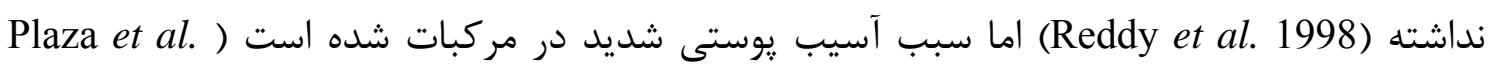
2004). همجنين اسانس ليمو روى ميوه گوجهفرنكى علائمى ايجاد نكرده ولى عوارض و علائم

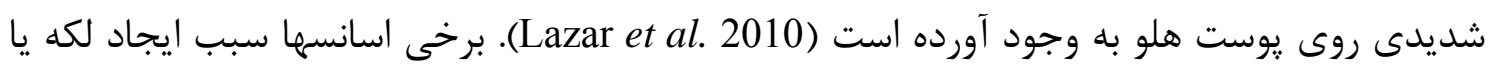

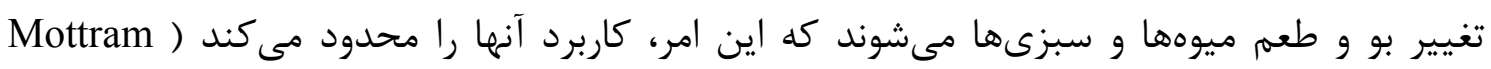

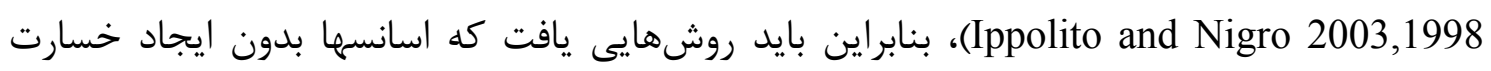

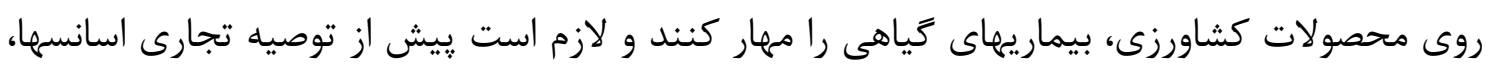

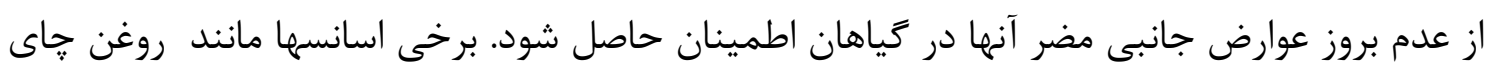
در مقادير زياد براى حيوانات سمى (Melaleuca alternifolia (Maiden and Betche) Cheel)

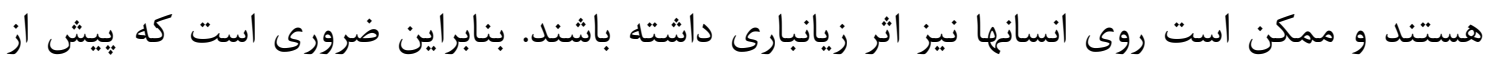

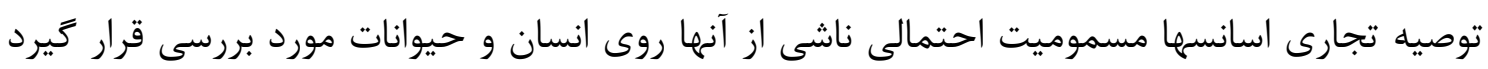




$$
\text { جدول ا - اثر بازدارندگى برخى اسانسها بر بيماركرهاى قارجى گياهى }
$$

Table 1. Inhibition effect of selected essential oils on fungal plant pathogens

\begin{tabular}{|c|c|c|c|c|}
\hline $\begin{array}{l}\text { Source plant for essential } \\
\text { oil extraction }\end{array}$ & Target organism & $\begin{array}{l}\text { Essential oil } \\
\text { concentration }\end{array}$ & $\begin{array}{l}\text { Inhibition } \\
(\%)\end{array}$ & References \\
\hline $\begin{array}{l}\text { Carum ) زيره سياه قفقازى } \\
\text { (copticum (L.) C. Clarke }\end{array}$ & Alternaria solani & ppm 400 & 100 & $\begin{array}{l}\text { Babagoli and } \\
\text { Behdad } 2012\end{array}$ \\
\hline $\begin{array}{c}\text { Thymus ( آويشن باغى } \\
\text { (vulgaris }\end{array}$ & Penicillium italicum & $\left(\mu \mathrm{L} \mathrm{mL}^{-1}\right) 0.13$ & 100 & $\begin{array}{l}\text { Vitoratos et al. } \\
2013\end{array}$ \\
\hline ليمو (Citrus limon L) & Botrytis cinerea & $\left(\mu \mathrm{L} \mathrm{mL}^{-1}\right) 17$ & 100 & $\begin{array}{c}\text { Vitoratos et al. } \\
2013\end{array}$ \\
\hline $\begin{array}{c}\text { Cymbopogon ) علف ليمو } \\
\text { flexuosus (Nees ex } \\
\text { (Steud.) Wats }\end{array}$ & $\begin{array}{l}\text { Alternaria alternate } \\
\text { Fusarium semitectum } \\
\text { Lasiodiplodia } \\
\text { theobromae } \\
\text { Rhizopus stolonifer }\end{array}$ & اسانس خالص (روش در ديسك) & 100 & $\begin{array}{l}\text { Espitia et al. } \\
2012\end{array}$ \\
\hline $\begin{array}{l}\text { Foeniculum ) رازيانه } \\
\text { (.vulgare Mill }\end{array}$ & Sclerotinia sclerotiorum & $\left(\mu \mathrm{L} \mathrm{L}^{-1}\right) 150$ & 100 & $\begin{array}{c}\text { تيمورى و رهنما } \\
\text { روسا }\end{array}$ \\
\hline $\begin{array}{c}\text { آويشن شيرازى (multiflora Boiss } \\
\text { (mutaria }\end{array}$ & Phytophthora drechsleri & $\left(\mu \mathrm{L} \mathrm{L}^{-1}\right) 1000$ & 100 & $\begin{array}{l}\text { Mohammadi et } \\
\text { al. } 2015\end{array}$ \\
\hline $\begin{array}{c}\text { Thymus ) آويشن } \\
\text { kotschyanus Boiss. and } \\
\text { (Hohen }\end{array}$ & Botrytis cinerea & $\left(\mu \mathrm{L} \mathrm{L}^{-1}\right) 300$ & 100 & حسنى و همكاران \\
\hline $\begin{array}{l}\text { Lavandula (سطوخدوس (angustifolia Mill. } \\
\text { (ang }\end{array}$ & $\begin{array}{l}\text { Botrytis cinerea, } \\
\text { Rhizopus stolonifer, } \\
\text { Aspergillus niger }\end{array}$ & $\left(\mu \mathrm{L} \mathrm{L}^{-1}\right) 1000$ & 100 & 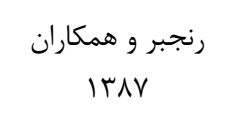 \\
\hline $\begin{array}{c}\text { Thymus ( آويشن دنايى } \\
\text { (daenensis Celak }\end{array}$ & & $\left(\mu \mathrm{L} \mathrm{L}^{-1}\right) 600$ & & \\
\hline $\begin{array}{c}\text { Mentha (piperita L. } \\
\text { (piele }\end{array}$ & Penicillium expansum & $\left(\mu \mathrm{L} \mathrm{L}^{-1}\right) 300$ & 100 & صفرى و همكاران \\
\hline 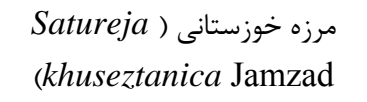 & & $\left(\mu \mathrm{L} \mathrm{mL}^{-1}\right) 600$ & & \\
\hline $\begin{array}{c}\text { مخلوط اسانس رازيانه و رزمارى } \\
\text { Rosmarinus officinalis ) } \\
\text { (L. }\end{array}$ & Fusarium oxysporum & (ppm) 100 & 100 & سمالك معراجى و \\
\hline $\begin{array}{l}\text { Cuminum ) زيره سبزه سياه (cyminum L. } \\
\text { (Carum carvi L.) }\end{array}$ & Botrytis cinerea & $\begin{array}{l}(\mathrm{ppm}) 200 \\
(\mathrm{ppm}) 800\end{array}$ & 100 & 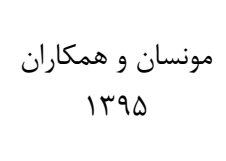 \\
\hline 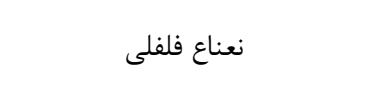 & $\begin{array}{l}\text { Cladosporium } \\
\text { oxysporum }\end{array}$ & $\left(\mu \mathrm{L} \mathrm{L}^{-1}\right) 600$ & 100 & جهرى و حيدرىنيا \\
\hline 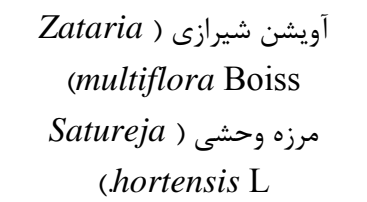 & Botrytis cinerea & (ppm) 200 & 100 & ذاكر و همكاران \\
\hline
\end{tabular}




$$
\text { جدول ا- اثر بازدارندگى برخى اسانسها بر بيمارگرهاى قار جى گياهى (ادامه) }
$$

Table 1. Inhibition effect of selected essential oils on fungal plant pathogens (Continue)

\begin{tabular}{|c|c|c|c|c|}
\hline $\begin{array}{l}\text { Source plant for } \\
\text { essential } \\
\text { oil extraction } \\
\end{array}$ & Target organism & $\begin{array}{l}\text { Essential oil } \\
\text { concentration }\end{array}$ & $\begin{array}{l}\text { Inhibition } \\
(\%)\end{array}$ & References \\
\hline مرزه وحشى & \multirow[t]{3}{*}{ Aspergillus flavus } & $\begin{array}{c}400 \\
\left(\mu \mathrm{L} \mathrm{L}^{-1}\right)\end{array}$ & 100 & 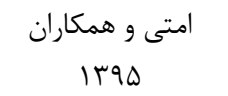 \\
\hline جمن معطر & & (ppm) 100 & 21 & \multirow{8}{*}{ Ojo 2014} \\
\hline Cymbopogon ) & & (ppm) 300 & 54 & \\
\hline (flexuosus & \multirow{5}{*}{ Penicillium digitatum } & (ppm) 600 & 71 & \\
\hline Ocimum ) بحان, & & (ppm) 600 & 10 & \\
\hline (aratissimum & & $(\mathrm{ppm}) 900$ & 29 & \\
\hline & & (ppm) 1200 & 35 & \\
\hline به ليمو (lippia alba) & & \multirow{5}{*}{ (ppm) 500} & 20 & \\
\hline $\begin{array}{l}\text { Callistemon ) شيشهشور } \\
\text { (lanceolatus }\end{array}$ & \multirow{5}{*}{ Botrytis cinerea } & & 25 & \\
\hline بالنَ (Citrus medica) & & & 30 & \multirow{3}{*}{$\begin{array}{l}\text { Tripathi et al. } \\
\quad 2008\end{array}$} \\
\hline $\begin{array}{l}\text { Citrus ( نارنكى } \\
\text { (reticulata }\end{array}$ & & & 45 & \\
\hline 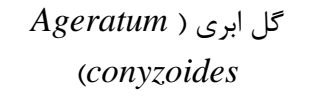 & & & 60 & \\
\hline & & & & آزمايشهاى در زيوه \\
\hline $\begin{array}{l}\text { Thymus ) آويشن باغى } \\
\text { (vulgaris L. }\end{array}$ & Botrytis cinerea & $\left(\mu \mathrm{LL}^{-1}\right) 500$ & 100 & $\begin{array}{c}\text { Gebel and } \\
\text { Magurno } 2014\end{array}$ \\
\hline آويشن شيرازى آويش & Alternaria citri & $\begin{array}{c}500 \\
\left(\mu \mathrm{L} \mathrm{L}^{-1}\right)\end{array}$ & 100 & $\begin{array}{l}\text { Ramezanian et } \\
\text { al. } 2016\end{array}$ \\
\hline $\begin{array}{l}\text { خردل حينى (juncea L. } \\
\text { Brassica }\end{array}$ & $\begin{array}{l}\text { Colletotrichum } \\
\text { gloeosporioides }\end{array}$ & (ppm) 250 & 80 & $\begin{array}{l}\text { Abd-Alla and } \\
\text { Haggag } 2013\end{array}$ \\
\hline $\begin{array}{c}\text { مخلوط اسانس ميخك هندى } \\
\text { Syzygium ) } \\
\text { و (aromaticum L. } \\
\text { (رزمارى }\end{array}$ & \multirow[t]{3}{*}{ Podosphaera xanthii } & 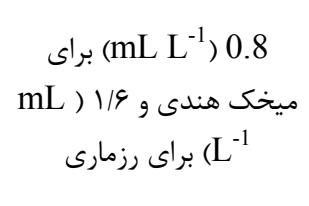 & 16 & $\begin{array}{l}\text { Sturchio et al. } \\
2014\end{array}$ \\
\hline (ار حين ( Cinnamomum & & $\left(\mu \mathrm{L} \mathrm{mL}^{-1}\right) 10$ & 53 & \multirow{3}{*}{$\begin{array}{l}\text { Kishore et al. } \\
\quad 2007\end{array}$} \\
\hline (zeylanicum & & $\begin{array}{l}\left(\mu \mathrm{L} \mathrm{mL}^{-1}\right) 5 \\
\left(\mu \mathrm{LL}^{-1}\right) 10\end{array}$ & $\begin{array}{l}37 \\
58\end{array}$ & \\
\hline $\begin{array}{l}\text { Syzygium ) ميخك } \\
\text { (aromaticum }\end{array}$ & & $\left(\mu \mathrm{L} \mathrm{mL} L^{-1}\right) 5$ & 42 & \\
\hline ر ازيانه & Botrytis cinerea & $\left(\mu \mathrm{L} \mathrm{L}^{-1}\right) 1000$ & 15 & هيغامى آشنايى و \\
\hline 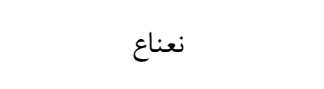 & Penicillium spp. & $\left(\mathrm{mL} \mathrm{L}^{-1}\right) 750$ & 74 & 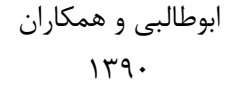 \\
\hline
\end{tabular}




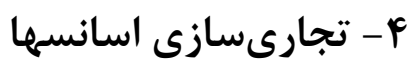

اكرجه يزوهشها نشان داده است كه برخى اسانسها به اندازه تركيبات شيميايى در مهار برخى بيماريهاى كَياهى مؤثرند، از نظر صنعتى، تاكنون رغبت حندانى نسبت به تجارىسازى اسانسها به عنوان جايكزين سموم شيميايى وجود نداشته است. اين موضوع ناشى از كارايى پايينتر اغلب اسانسها

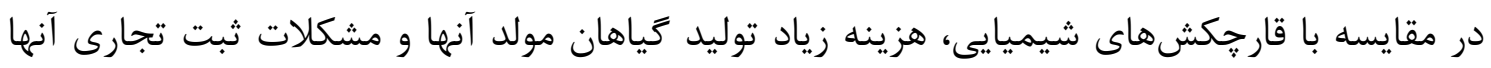

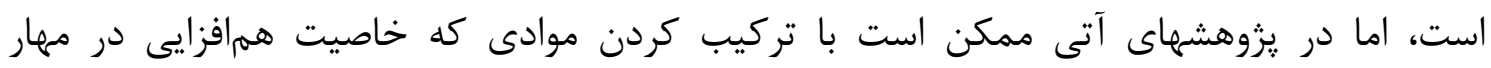

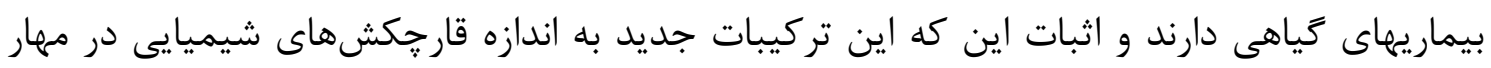
بيماريهاى كياهى مؤثرند، بر اين مشكلات غلبه شود. با وجود اين مشكلات، برخى اسانسها به صورت

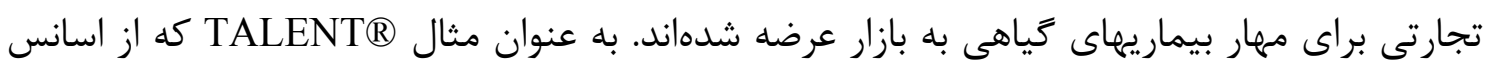

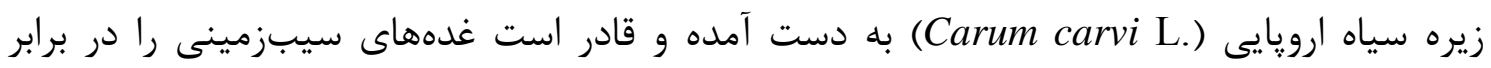

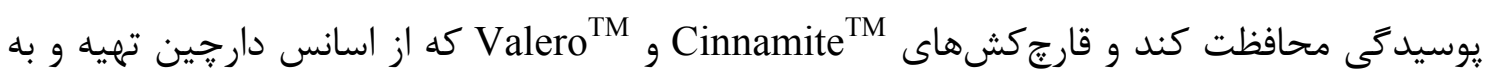

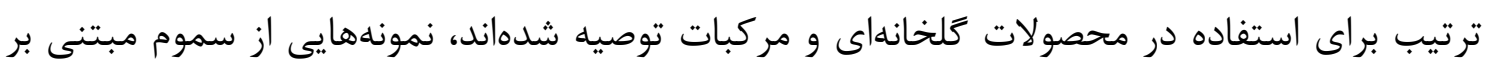
اسانسهاى كياهى ارائه شده به بازار هستند (Isman 2000, Bishop and Thornton 1997). نتيجه تيرى

برخى اسانسهاى گياهى به دليل فعاليت قابل توجه در برابر قار خهاى بيماركر گياهان، توان بالقوه

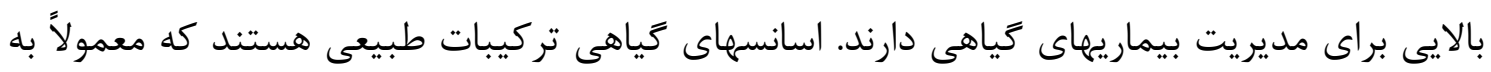

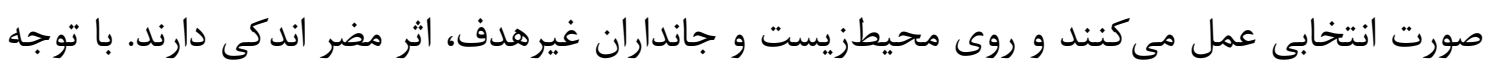

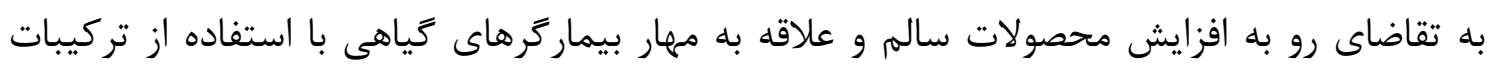
طبيعى به نظر مىرسد كه بازار قابل توجهى براى قارجكشهاى مبتنى بر اسانسها در دنيا وجود دارد.

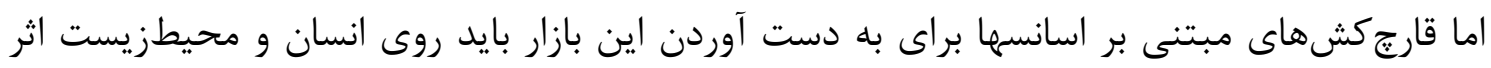

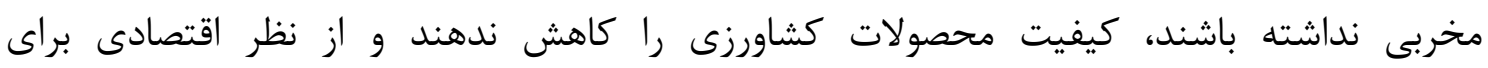

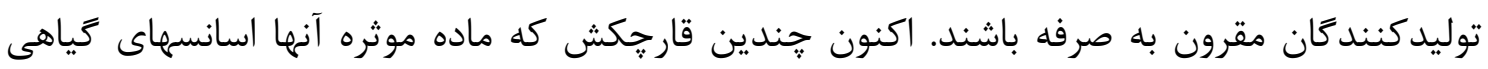

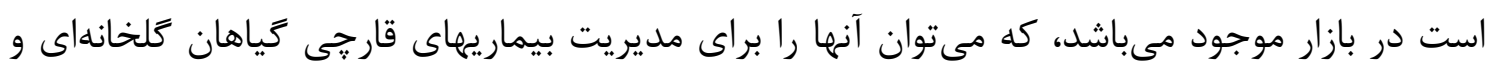

$$
\text { درختان ميوه پيشنهاد كرد. }
$$

\section{References}

1. ابوطالبى ع. و محمدى م. •وبا. اثر اسانس كياهان داروئى بر ثبات كيفيت و مديريت

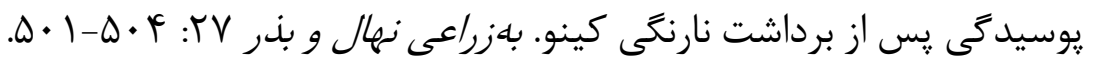




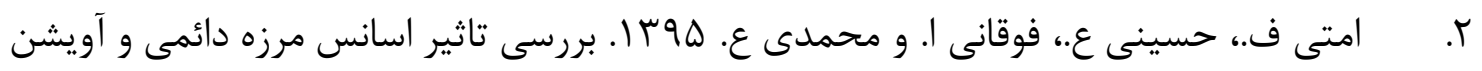
شيرازى در كنترل قارج Aspergillus flavus مولد آفلاتوكسين. دومين همايش ملى بايش و

$$
\text { ييش آكاهى در كياهيزشكى. كنبد كاووس، ايران. }
$$

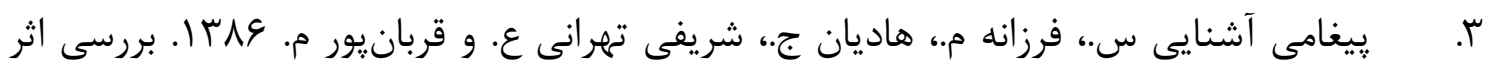

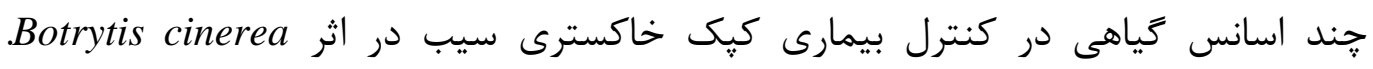

$$
\text { يزوهش كشاورزى: آب، خاى و حياه در كشاورزى Vا: • •1-1. }
$$

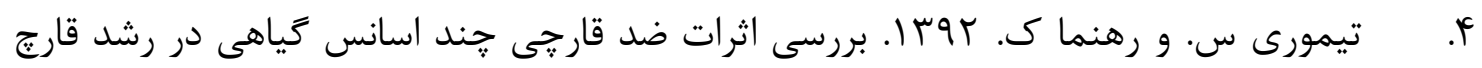
عامل يوسيدگى سفيد ساقه كلزا (Sclerotinia sclerotiorum) در شرايط آزمايشكاه. تحقيقات

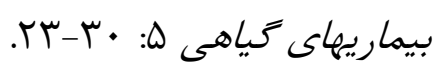

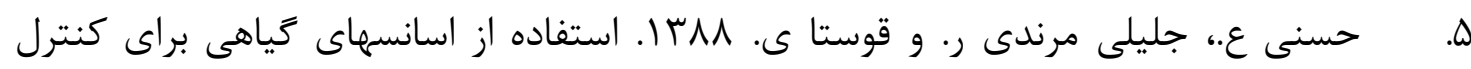

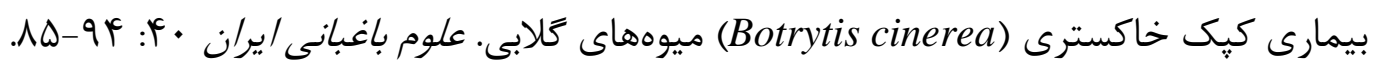

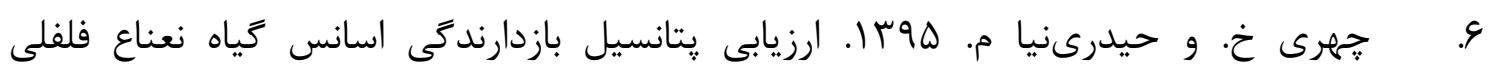
Penicillium و Cladosporium oxysporum روى رشد قارجيهای (Mentha piperita) oxalicum r

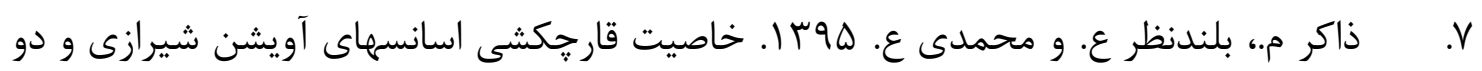

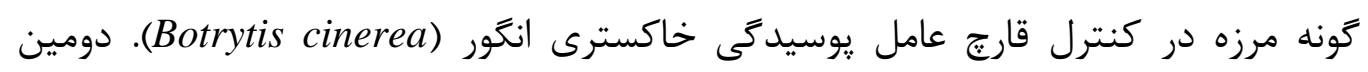

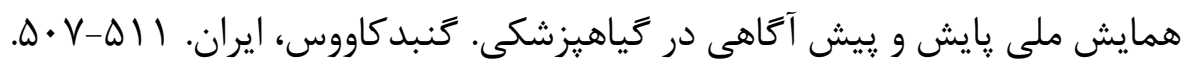

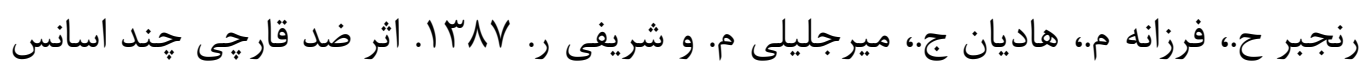
.$\wedge$

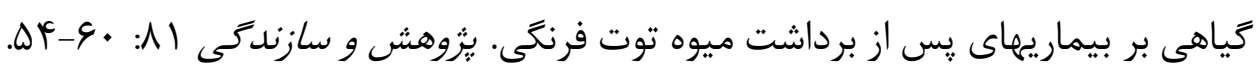

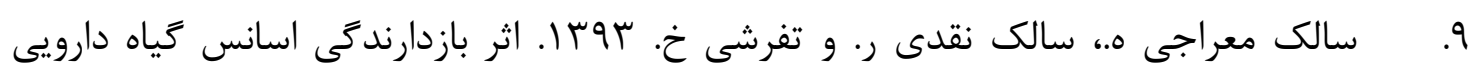

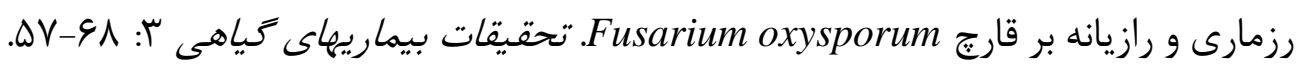

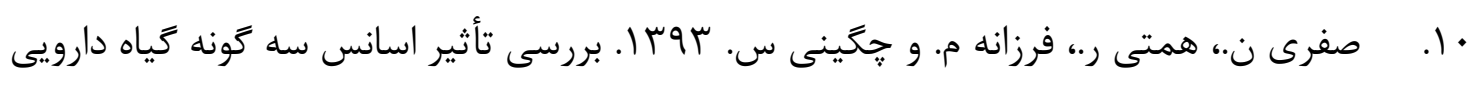

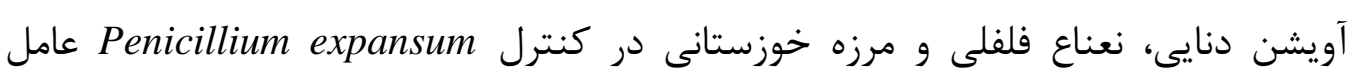

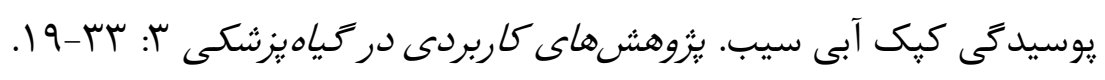

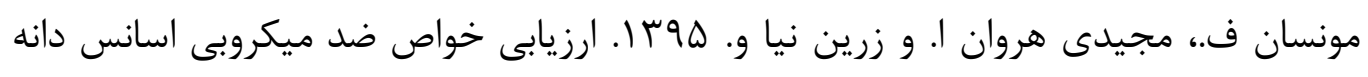

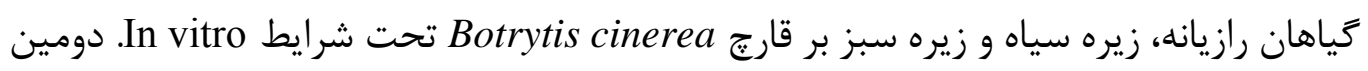

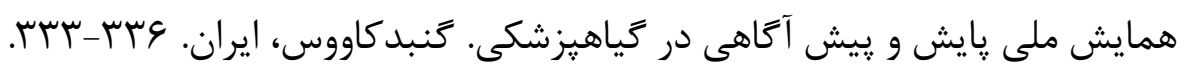


12. Abd-Alla M. A. and Haggag W. M. 2013. Use of some plant essential oils as postharvest botanical fungicides in the management of anthracnose disease of mango fruits (Mangi feraindica L.) caused by Colletotrichum gloeosporioides (penz). International Journal of Agriculture and Forestry 3:1-6.

13. Arshad Z., Hanif M. A., Qadri R. W. K., Khan M. M., Babarinde A., Omisore G. O., Babalola J. O., Syed S., Mahmood Z., Riaz M. and Latif S. 2014. Role of essential oils in plant diseases protection: a review. International Journal of Chemical and Biochemical Sciences 6:11-17.

14. Babagoli M. A. and Behdad E. 2012. Effects of three essential oils on the growth of the fungus Alternaria solani. Journal of Research in Agricultural Science 8:4557.

15. Bakkali F., Averbeck S., Averbeck D., Zhiri A., Baudoux D. and Idaomar M. 2006. Antigenotoxic effects of three essential oils in diploid yeast (Saccharomyces cerevisiae) after treatments with UVC radiation, 8-MOP plus UVA and MMS. Mutation Research 606: 27-38.

16. Bishop C. D. and Thornton I. B. 1997. Evaluation of the antifungal activity of the essential oils of Monarda citriodora var. citriodora and Melaleuca alternifolia on post-harvest pathogens. Journal of Essential Oil Research 9:77-82.

17. Burt S. 2004. Essential oils: their antibacterial properties and potential applications in foods-a review. International Journal of Food Microbiology 94:223-253.

18. Chen Y., Zeng H., Tian J., Ban X., Ma B. and Wang Y. 2013. Antifungal mechanism of essential oil from Anethum graveolens seeds against Candida albicans. Journal of medical microbiology, 62:1175-1183.

19. Crosthwaite D. 1998. UK trade within the flavour and fragrance industry. Proceedings of $21^{\text {st }}$ International Conference on Essential Oils and Aroma's, London, England, pp. 6-12.

20. de Billerbeck V. G., Roques C. G., Bessière J. M., Fonvieille J. L. and Dargent R. 2001. Effects of Cymbopogon nardus (L.) W. Watson essential oil on the growth and morphogenesis of Aspergillus niger. Canadian Journal of Microbiology 47:917.

21. Espitia P., Soares N., Botti L., Melo N., Pereira O. and Silva W. 2012. Assessment of the efficiency of essential oils in the preservation of postharvest papaya in an antimicrobial packaging system. Brazilian Journal of Food Technology 15:333-342.

22. Gebel M. P. and Magurno F. 2014. Assessment of the antifungal potential of the essential oil from Thymus vulgaris against Botrytis cinerea causative agent of postharvest grey mould on strawberry fruits. Columella: Journal of Agricultural and Environmental Sciences 1:17-24.

23. Guenther E. 1948.The Essential Oils. D. Van Nostrand Press, New York,USA, $214 p$. 
24. Hadacek F. and Greger H. 2000. Testing of antifungal natural products: methodologies, comparability of results and assay choice. Phytochemical Analysis 11:137-147.

25. Hammer K., Carson C. and Riley T. 2004. Antifungal effects of Melaleuca alternifolia (tea tree) oil and its components on Candida albicans, Candida glabrata and Saccharomyces cerevisiae. Journal of Antimicrobial Chemotherapy 53:1081-1085.

26. Ippolito A. and Nigro F. 2003. Natural antimicrobials in postharvest storage of fresh fruits and vegetables. Pp: 201-234. In: S. Roller (ed.). Natural Antimicrobials for the Minimal Processing of foods, Woodhead Publishing, England.

27. Iscan G., Iscan A. and Demirci F. 2016. Anticandidal effects of thymoquinone: Mode of action determined by transmission electron microscopy (TEM). Natural Product Communications 11:977-978.

28. Isman M. B. and Machial C. M. 2006. Pesticides based on plant essential oils: from traditional practice to commercialization. Pp: 29-44. In: M. Rai and M. C. Carpinella (eds.). Naturally Occurring Bioactive Compounds, Elsevier, USA.

29. Isman M. B. 2000. Plant essential oils for pest and disease management. Crop protection 19:603-608.

30. Kishore G. K., Pande S. and Harish S. 2007. Evaluation of essential oils and their components for broad-spectrum antifungal activity and control of late leaf spot and crown rot diseases in peanut. Plant Disease 91:375-379.

31. Kong W., Huang C., Chen Q., Zou Y. and Zhang J. 2012. Nitric oxide alleviates heat stress-induced oxidative damage in Pleurotus eryngii var. tuoliensis. Fungal Genetics and Biology 49:15-20.

32. Kurita N., Miyaji M., Kurane R. and Takahara Y. 1981. Antifungal activity of components of essential oils. Agricultural and Biological Chemistry 45:945-952.

33. Lanciotti R., Gianotti A., Patrignani F., Belletti N., Guerzoni M. E. and Gardini F. 2004. Use of natural aroma compounds to improve shelf-life and safety of minimally processed fruits. Trends in Food Science and Technology 15:201-208.

34. Lazar E. E., Jobling J. J. and Benkeblia N. 2010. Postharvest disease management of horticultural produce using essential oils: Today's prospects. Stewart Postharvest Review 3:1-10

35. Mishra A. K. and Dubey N. K. 1994. Evaluation of some essential oils for their toxicity against fungi causing deterioration of stored food commodities. Applied and Environmental Microbiology 60:1101-1105.

36. Mohammadi A., Hashemi M. and Hosseini S. M. 2015. Comparison of antifungal activities of various essential oils on the Phytophthora drechsleri, the causal agent of fruit decay. Iranian Journal of Microbiology 7:31-37.

37. Mottram D.S. 1998. Chemical tainting of foods. International Journal of Food Science and Technology 33:19-29. 
38. Ojo O. 2014. Antifungal activity of essential oils from some tropical plants against Penicillium digitatum infected Citrus sinensis fruit during storage. International Journal of Agriculture and Crop Sciences 7:981-987.

39. Plaza P., Torres R., Usall J., Lamarca N. and Vinas I. 2004. Evaluation of the potential of commercial post-harvest application of essential oils to control citrus decay. The Journal of Horticultural Science and Biotechnology 79:935-940.

40. Ramezanian A., Azadi M., Mostowfizadeh-Ghalamfarsa R. and Saharkhiz M. J. 2016. Effect of Zataria multiflora Boiss and Thymus vulgaris L. essential oils on black rot of 'Washington Navel'orange fruit. Postharvest Biology and Technology 112:152-158.

41. Rasooli I., Rezaei M. B. and Allameh A. 2006. Growth inhibition and morphological alterations of Aspergillus niger by essential oils from Thymus eriocalyx and Thymus x-porlock. Food Control 17:359-364.

42. Reddy M. B., Angers P., Gosselin A. and Arul J. 1998. Characterization and use of essential oil from Thymus vulgaris against Botrytis cinerea and Rhizopus stolonifer in strawberry fruits. Phytochemistry 47:1515-1520.

43. Sharma N. and Tripathi A. 2006. Fungitoxicity of the essential oil of Citrus sinensis on post-harvest pathogens. World Journal of Microbiology and Biotechnology 22:587-593.

44. Shen Q., Zhou W., Li H., Hu L. and Mo H. 2016. ROS involves the fungicidal actions of thymol against spores of Aspergillus flavus via the induction of nitric oxide. PloS One 11:e0155647.

45. Souza E., Lima E., Freire K. and Sousa C. 2005. Inhibitory action of some essential oils and phytochemicals on the growth of various moulds isolated from foods. Brazilian Archives of Biology and Technology 48:245-250.

46. Sturchio E., Donnarumma L., Annesi T., Milano F., Casorri L., Masciarelli E., Zanellato M., Meconi C. and Boccia P. 2014. Essential oils: an alternative approach to management of powdery mildew diseases. Phytopathologia Mediterranea 53:385-395.

47. Tripathi P., Dubey N. and Shukla A. 2008. Use of some essential oils as postharvest botanical fungicides in the management of grey mould of grapes caused by Botrytis cinerea. World Journal of Microbiology and Biotechnology 24:39-46.

48. Villar D., Knight M. J., Hansen S. R. and Buck W. B. 1994. Toxicity of melaleuca oil and related essential oils applied topically on dogs and cats. Veterinary and Human Toxicology 36:139-142.

49. Vitoratos A., Bilalis D., Karkanis A. and Efthimiadou A. 2013. Antifungal activity of plant essential oils against Botrytis cinerea, Penicillium italicum and Penicillium digitatum. Notulae Botanicae Horti Agrobotanici Cluj-Napoca 41:8692.

50. Yutani M., Hashimoto Y., Ogita A., Kubo I., Tanaka T. and Fujita, K.I. 2011. Morphological changes of the filamentous fungus Mucor mucedo and inhibition 
of chitin synthase activity induced by anethole. Phytotherapy Research 25:17071713 .

51. Zambonelli A., d'Aulerio A. Z., Bianchi A. and Albasini A. 1996. Effects of essential oils on phytopathogenic fungi in vitro. Journal of Phytopathology 144:491-494. 